\title{
A Review on Motion Event from a Typological Perspective
}

\author{
Xinxin Shan \\ College of International Studies, Southwest University, Chongqing, China
}

\begin{abstract}
In light of the lexicalization patterns as proposed by Talmy $(1985,1991,2000)$ and Slobin's "Thinking for Speaking" hypothesis $(1991,1996,2000)$, this paper provides a review on motion event from a typological perspective. Also, a constellation of studies on the classification of Chinese in motion event typology has been presented and discussed. These works advance our knowledge of motion research, and set the stage for subsequent research on how motion expressions are understood and used in everyday communication.
\end{abstract}

Index Terms-motion event, motion event typology, satellite-framed languages, verb-framed languages, equipollently-framed languages

\section{INTRODUCTION}

In the last several decades, there has been an increasing interest in the research of motion events, as well as their descriptions in typologically different languages. It has become almost impossible to consider motion-event descriptions from a typological perspective without starting from the seminal work of Talmy $(1985,1991,2000)$, and its application to narrative and to the issue of linguistic relativity by Slobin (1996a, 1996b, 1997a, 1997b, 2000), as also testified by many of the contributions to this volume (cf. Ibarretxe-Antuñano, Zlatev \& Yangklang, Ameka \& Essegbey, Tai, Papafragou, Massey \& Gleitman, and Wen \& Shan).

\section{TALMY’s LingUistic TyPOLOGY OF MOTION EvENTS}

Motion events, as Talmy (1985, p. 61) describes, is a situation "containing movement or maintenance of a stationary location". Motion is one of the most essential and pervasive experiences, which can be subdivided into two kinds: self-contained motion and translational motion. The former refers to motion without a change of location in space, such as rotation, oscillation, or dilation, while the latter denotes motion of an object whose location in space makes a change. In Talmian research on typology of lexicalization patterns of motion events, translational motion is among the major subjects.

According to Talmy (2000), a motion event consists of six basic semantic components, while the first four elements constituting the central or "internal components", the last two are associated or "external co-event components". These are: Figure, Ground, Path, Motion, Manner and Cause.

(1) The internal components of a motion event

Figure: the object that moves

Ground: the entity that the Figure is moving in relation to

Path: the trajectory of the Figure or the course followed by the Figure with respect to the Ground

Motion: the fact that some entity changes its location

(2) The external co-event components of a motion event

Manner: the way in which the Motion is performed

Cause: the cause due to which the Motion originates

These components can be illustrated with some of Talmy's classical examples (1985, p. 61):

(3) The pencil off rolled the table

[figure] [motion+manner] [path] [ground]

(4) The pencil blew off the table

[figure] [motion+cause] [path] [ground]

In both sentences the pencil and the table functions as the figure and the ground respectively, and the particle off plays the role of the path. As for the motion part, in (3), the manner component is conflated with the motion component, and the verb rolled specifies that the manner of movement. In (4), it is the cause component that is conflated with the motion component and the verb blew specifies the cause of the movement of the pencil, which is the figure object.

Talmy (1991) has identified the core schema ("the association function that sets the figural entity into a particular relationship with the ground entity", Talmy, 2000, p. 218) of motion events as being the path dimension of motion, i.e., corresponds to the category of path. Therefore, among the six semantic components of a motion event, path is generally regarded as the core feature of the event, and languages differ significantly in that the distinction in the way the core feature of an event is expressed. 
According to Talmy (1985, 2000), languages generally fall into two basic typological categories: "verb-framed" languages and "satellite-framed" languages (V-languages and S-languages), on the basis of how they encode the core information about the path of movement. The former languages encode the core feature in the verb, while the latter in a "satellite" (e.g., verb particles, prefixes) to the verb, and the verb expresses the co-event, usually manner or cause. The distinction of the verb stem or the "satellite" is supposed to cut a line through the world's languages, as stated by Talmy:

Languages that characteristically map the core schema into the verb will be said to have a framing verb and to be verb-framed. Included among such languages are Romance, Semitic, Japanese, Tamil, Polynesian, most Bantu, most Mayan, Nez Perce, and Caddo. On the other hand, languages that characteristically map the core schema onto the satellite will be said to have a framing satellite and to be satellite-framed languages, and included among them are most Indo-European minus Romance, Finno-Ugric, Chinese, Ojibwa and Warlpiri. (Talmy, 2000, p. 222)

For instance, English, which is a typical S-language, characteristically encode the path in the subordinate satellite element associated with a verb such as a particle (in, out, across), whereas V-languages as Spanish, encode the path in the main verb in a clause more frequently (e.g., equivalents of enter, exit, ascend, descend, etc.). This contrast can be best illustrated by example (5) from Slobin (1997b).

(5) English Original

I ran out the kitchen door,

Spanish Translation

past the animal pens,

Salí por la puerta de la cocina

"I exited [by] the kitchen door"

toward Jasón's house.

pasé por los corrale

"passed by the animal pens"

y me dirigí a casa de Jasón

"and directed myself to Jasón's house"

These two categories of languages also differ in their preferences for encoding manner of movement. In other words, S-languages typically encode manner of movement in the verb, whereas V-languages usually use subordinate elements to describe the manner. Therefore, to describe a scene in which a man ran as he entered a house, an English speaker would most likely say The man ran into the room., rather than The man came into the room, running., even though both are possible for this S-framed language. In contrast, a speaker of Spanish will most likely indicate that motion has occurred in a particular direction, without indication of manner. Instead, a "supporting information" about manner of movement may conveyed by a gerundive form corriendo (equivalent of "running"). As Talmy (1985, 2000) points out, the gerundive or adverbial type of constituent can be "stylistically awkward", thus in some circumstances, information about manner or cause of movement is "often either established in the surrounding discourse or omitted altogether" (Talmy, 1985, p. 69).

All in all, English speakers explicitly and obligatorily indicates manner in the verb and path in the adverbial particle. This pattern contrasts with that of Spanish, the speakers of which are forced by their language to use path verbs, whereas manner is confined to an optional adverbial modifier. In sum, to talk about culminated events, English speakers typically encode both manner and path, while Spanish speakers encode path in the verb and tend to left manner unexpressed (Gennari et al, 2002).

It is worth mentioning that English also has certain verbs that encode information about path and that can be used as main verbs (rise, enter, exit, ascend, descend, advance, proceed, approach, arrive, depart, return, separate, part, etc.). However, most of such verbs are borrowed from French or other Romance languages that they are not the typical means of expressing motion events in English. Similarly, certain manner verbs in Spanish can also be used as the main verbs to describe motion events. Yet again, this is not the preferred way of expressing motion events in Spanish.

\section{SLOBIN's “ThINKING FOR SPEAKING” HYPOTHESIS}

As described in the previous section, speakers of English and Spanish differ in how they talk about the same observed change of location. The typological differences across languages show that languages have different syntactic-semantic preferences when their speakers talk about motion.

By comparing the ways in which speakers of different languages depict the same events in orally elicited narratives as well as in written texts based on a wordless story-book, Frog, where are you? (Mayer, 1969), Slobin proposes that such typological linguistic differences have also been shown to impact the structure of an entire narrative, and lands on the conclusion that "the form and content of descriptions of journeys are heavily shaped by the typology of lexicalization patterns" (1996a, p. 195). Several contrasts have been observed between S-languages and V-languages, and those structural differences have significant and predictable implications for the organization of connected discourse in the two language types.

Slobin's (1997b) proposals regarding motion event descriptions in S- versus V-languages

Regarding manner

a. V-language users express manner only when it is absolutely needed, and typically, translational motion takes precedence.

b. S-languages have a larger and more diverse lexicon of manner verbs than V-languages.

c. Manner verbs in S-languages are more expressive than those in V-languages.

regarding path 
d. V-language users mention fewer path segments than S-language users do when describing comparable motion events.

regarding ground

e. V-language users use fewer ground elements per clause than S-language users do.

f. V-language users are more likely to use motion verbs without any ground information in the clause than S-language users.

regarding rhetorical style

g. V-language users devote more attention to describing aspects of the static scene which provides the physical context for a motion event, whereas S-language users devote more attention to descriptions of the process of motion.

This pattern of differences between S- and V-languages in language use has been examined by independent researchers working on a variety of languages (e.g., Slobin, 1997b; Ibarretxe-Antuñano, 2004; Papafragou, Massey \& Gleitman, 2006, etc.), and is "apparently independent of language family, geographical area, and culture" (Slobin, 2003, p. 164).

To account for the systematic differences in patterns of language use (e.g., narration of motion events in stories) by narrators of typologically different languages, Slobin (1996b) proposes what he calls "Thinking for Speaking" hypothesis, which is a modified version of the classic Sapir-Whorf arguments on linguistic relativity and determinism that were much debated in the first half of the twentieth century. The two critical terms of Sapir -Whorf hypothesis are thought and language, which are inseparable. Languages vary from one another; thereby each speech community embodies a distinct world-view. Slobin (1996b, p. 71), however, replaces thought and language with a related yet different pair of terms: thinking and speaking, in order to draw attention to the mental processes that occur during the act of formulating an utterance. The difference between Slobin's hypothesis and Sapir and Whorf's view is that the main goal of the latter is not to prove the effects of grammar on world-view or non-linguistic behavior, but to "focus attention just on those parts of utterances that are acquired by the grammatical organization of the language" (ibid.), and to demonstrate how speakers of a language organize their thinking in line with the linguistic tools offered by that language, i.e. how "the thinking is carried out, on-line, in the process of speaking" (Slobin, 1991, p. 11). According to his own formulation,

The expression of experience in linguistic terms constitutes thinking for speaking - a special form of thought that is mobilized for communication... We encounter the contents of the mind in a special way when they are being accessed for use. That is, the activity of thinking takes on a particular quality when it is employed in the activity of speaking. In the evanescent time frame of constructing utterances in discourse one fits one's thoughts into available linguistic frames. "Thinking for speaking" involves picking those characteristics of objects and events that (a) fit some conceptualization of the event, and (b) are readily encodable in the language (ibid., p, 12).

That is to say, an experience cannot be expressed unless the speaker takes a specific perspective influenced, if not determined, by the typological characteristics and lexicalization patterns of a given language. We perceive the same events but choose the different ways to talk about them, and that is what language presents to us. Therefore, Slobin (1996a) suggests that any event, i.e., a motion event, can be described in terms of two different cognitive frames. The one which he calls a "discourse frame" refers to the actual event or experience that we want to describe, and a "typological frame", on the other hand, depicts the domain that the tools provided for and constraints imposed on speakers in verbalizing that event in a particular language.

The "Thinking for Speaking" hypothesis also claims that there is a special kind of thinking that is intimately tied to language. That is to say, besides speaking, the thinking carried out on-line in the process of writing and reading, talking and listening, or translating, which can be confirmed respectively in motion events in creative fiction, in conversation and from one language type to the other (Slobin, 2000).

\section{The Typology OF Motion EXPRESSIONS Revisited}

Current cognitive linguistic research on the underlying conceptual organization of language has identified the "event" to be a basic building block of language and cognition (e.g., Goldberg, 1998; Talmy, 2000). From a typological perspective, motion events have received more attention than almost any other type of event. There have been indubitable signs since Talmy first suggested the intriguing proposal that language fall into two types with respect to how they encode directed motion events over thirty years ago (Talmy, 1972).

It is undoubted that Talmy's topological classification of motion events has been extremely influential. This generalization, however, does not apply to all lexicalizations of motion events. It has started to be modified more recently; new types have been proposed, by Talmy himself and by others, so as to account for languages that do not quite fit into this classification, or that go against the purported type.

Croft et al. (2002) point out that the original classification that Talmy proposed, i.e. satellite framing and verb framing, "... are asymmetric in their encoding of the semantic components of an event, which means one component is expressed by a verb predicate, and the other component by an element that cannot independently function as a verb predicate" (ibid., p, 206). But for the class of symmetric constructions in diverse set of languages, there seems different for the encoding of event and frame. In their serial verb constructions, for instance, Mandarin Chinese, or Thai, both event and frame are verbalized in forms that may occur as predicates on their own. This has also been observed by 
others (see also Zlatez \& Yangklang, 2004; Bohnemeyer et al., 2007), including Talmy himself, thus a third-serial construction has been added to the binary typology. However, besides the serial strategy, compounding and coordination also fall into the symmetric construction. Compounding is more grammaticalized; the two forms are morphologically bound, more closely integrated than the serial strategy. And a coordination construction can be used to express the combination of two components of a motion event, with the same subject in an appropriate context. Croft et al. (2002) identify another construction, a double framing construction, where "the path or framing expression is expressed twice, once as a detached satellite and once as part of the verb" (ibid.). Bohnemeyer et al. discover the type, too, describing it as "double marking" (Bohnemeyer et al., 2007). In their analysis, the double framing construction is not symmetrical, in that "the complex event is encoded partly in the verb form and partly by a satellite" (ibid.). Consequently, as Croft et al. suggests, Talmy's typological classification can be extended as follows:
b. Verb framing
c. Symmetrical
(6) a. Satellite framing

$$
\begin{aligned}
& \text { (e.g. English, Russian) } \\
& \text { (e.g. French, Spanish) } \\
& \text { (e.g. Thai) } \\
& \text { (e.g. Kiowa) } \\
& \text { (e.g. Amele) }
\end{aligned}
$$
(i) Serial
(ii) Compounding
(iii) Coordinate
d. Double framing
(e.g. French, Russian)

By examining the examples of $a, b$, and $d$, it is worth mentioning that Talmy's categorization has generally been taken as a topological classification of languages, which means, languages encode different motion events consistently with the same morphosyntactic type. Nevertheless, this is not the case. In fact, none of these languages are consistently one type or another in the expressing of events. Berman and Slobin also comment that "as a general caveat, it should be remembered that topological characterization often reflects tendencies rather than absolute differences between languages" (Berman \& Slobin, 1994, p. 18).

Speaking of Slobin, a more acceptable and putative broadened version of Talmy's typological classification is Slobin's trichotomy method of encoding complex events. Zlatev \& Yangklang (2004) argue that serializing languages share characteristics of both satellite- and verb-framing languages, and thus do not easily correspond to either of the patterns provided by Talmy's typology. In order to better account for typological distinctions, Slobin (2004) then introduces a third pattern - the Equipollently-framed pattern, mainly representing languages with serial verbs, and bi-partite verbs in which two (or more) verb stems are required to lexicalize motion events. Recently, more work extends Talmy's typology to include a third class of "E-framed languages", comprising languages in which "path and manner are expressed by equivalent grammatical forms" (ibid, p. 249).

Indeed, an important gap in the typology seems apparent when considering serializing languages, such as Thai (Zlatev \& Yangklang, 2004), or Ewe (Ameka \& Essegbey, 2006). The specificity of these languages is to express both path and manner equipollently in a single verb clause containing two (or more) obligatory verbs, i.e. one verb may express path and one or more verb may encode manner. That is to say, path and manner receive equal semantic emphasis within the same verb complex.

(7) a. Satellite-framed: Manner is encoded as a main verb; path must be a satellite.

b. Verb-framed: Path is encoded as a main verb; manner must be a subordinate adjunct.

c. Equipollently-framed: Path and manner are both encoded as main verbs.

In our analysis, we adopt the second elaboration of revised topological classification, for its strong influence and widely acceptance, to identify the place of Chinese in motion event typology.

\section{The Various Ways of Encoding Motion Events in Chinese}

Talmy's $(1985,1991,2000)$ binary typology is based on the way in which different languages across the world preferentially express path (i.e., change of location) in verbs or in elements associated with verbs. This is obvious for languages such as English and Spanish where distinct lexical categories or morphological markings are present to differentiate the main verb from its supporting elements. In these languages, there is only one verb slot in a clause. In satellite-framed languages (e.g., English and German), the verb slot is typically occupied by a manner-of-motion verb. In verb-framed languages (e.g., Spanish and French), the verb slot is typically occupied by a path verb and a manner verb is used as the main verb only if the clause does not assert a change of state (Slobin \& Hoiting, 1994). Consequently, in these languages, it is relatively easy to figure out which is the main lexical element, and which is the supporting element.

Chinese, however, makes use of a quite different strategy, where manner is typically expressed in the first verb and path is expressed in the second verb in a serial verb construction (V1 + V2) as in zǒu-jìn jiàoshì "walk-enter classroom". Chinese allows for at least two verb slots in a single clause: one for the path verb, and another or more for the manner. It always seems not quite clear that which verb is the main verb.

Therefore, the classification of Chinese in motion event typology has been a highly controversial issue, and a plethora of related studies recently inspire an increasing debate among linguists home and abroad.

\section{A. Chinese as a Satellite-framed Language}


Talmy (1985, 2000) claims that Chinese is a satellite-framed language, as he supposes that the specification of manner lies in the verb root, and the path information is encoded in another verb that functions as a complement to the manner verb. Before further analyzing Talmy's inspection toward the status of Chinese in motion event typology, we must first deal with a set of factors that tend to indicate that a language treats a particular constituent type as its main verb or verb root (Talmy, 2005) (cited in Ibarretxe-Antuñano, 2005).

\section{Principle}

(1) Factors that tend to mark a particular constituent type as the main verb (root)

Of two constituent types in a language that can be considered for having main verb status, one of them ranks higher for that status.

(1a). Morphology

if it can take inflections or clitics for such semantic categories as tense, aspect, mood, evidentiality, negation, causation, voice, transitivity, or the person, number, and gender of the subject (and object).

(1b). Syntax

if, as head, it directly or nestedly forms constructions with such other sentence constituents as: adverbs; particles for place, time, aspect, quantity (e.g., floats), negation, etc.; or a subject or object nominal.

(1c). co-occurrence patterns

if its presence is required across a range of construction types, while the other constituent type need not or cannot be present in some of those construction types.

(1d). class size

if it has more morpheme members or is open-class while the other constituent has fewer morpheme members or is closed-class.

(1e). phonology

(1e1). if its morpheme members have a greater average phonological length.

(1e2). if its morpheme members vary over a greater range of phonological length or pattern.

(1e3). if its morpheme members including phonemes ranging over a greater portion of the phonemic inventory of the language.

(1f). semantics

(1f1). if the meanings of its member morphemes tend to have more substantive content greater specificity, and a greater number of more varied conceptual components associated together in more intricate relationships, while those of the other constituent type tend to have less of these.

(1f2). if the meanings of its member morphemes range over a greater variety of concepts and types of concepts and trail off into more outlying conceptual areas, while those of the other constituent type tend to fit a more stereotyped semantic category.

(1f3). if it is experienced by speakers of the language as contributing the criterial component of actuation to the proposition that is otherwise represented by the sentence.

According to Talmy (ibid.), "different subsets of the factors apply to a specific constituent type in different languages, with no individual factor emerging as crucial. The more factors that converge on a particular constituent type in a language, the more that that constituent type is being privileged with main verb status". Typically, in Chinese, the verb in the first position of the serial construction, i.e. V1, expresses the co-event - either manner or cause, while the verb in the second position, V2, indicates the component of path; and there may be a third verb or V3, symbolizes the Deixis component of path.

Take the serial verb construction (V1 + V2) as in Tã zǒu-jìn jiàoshì "He walk-enter classroom" for example. Firstly, the former constituent type exhibits factor (1b). The motion verb zǒu "walk" functions as the head of the construction: it forms with jìn "enter", not vice versa. Further, it forms with the subject t $\bar{a}$ "he", with the place jiàoshì "classroom"; and the most importantly, it can be concatenated with adverbs. The former constituent type, in addition, demonstrates factor (1c) in that some representative of it must be present in a range of sentence types, whereas the latter one here represented by jìn "enter" can be excluded from many of those sentence types. By contrast, the reverse pattern, however, is minimal. For the factor (1d), the former constituent type is an open class with many morpheme members; the latter has fewer morpheme members or is closed-class. Finally, the first constituent shows evidence all three parts of factor (1f). Related to the second, on average, its member morphemes have greater specific content, as well as more semantic components together. They also range over a greater variety of meanings, while the latter tend to fit a more stereotyped semantic category of path. Moreover, they present the actuating or dynamizing feature. Consequently, on the basis of certain syntactic, co-occurrence, class size, and semantic behavior, V1 ranks higher than V2 for main verb status.

According to Talmy (ibid.), the verbs that occur in each of the two or three positions of the serials belong to different sets in general. He compares the verbs in each set, with the same verb when used as the sole verb, V0, in a sentence without a serial construction, to further identify which is the main verb or root. Here is the principle (2):

(2) Constituent-type overlap

If a language has two syntactically distinguishable constituent types that share some but not all of their morpheme members, then:

(2a). the degree of their divergence as distinct constituent types correlates with: 
(2a1). the proportion of non-overlap of their respective morpheme memberships and - for morphemes within the overlap -

(2a2). the proportion of morphemes whose meanings differ in the two constituent types

and

(2a3). the degree of such differences in meaning.

(2b). a morpheme occurring in both constituent types with basically the same meaning can seem to belong to a meta-category spanning both constituent types or belong to one category type even when functioning syntactically in the other type - more so than can a morpheme outside the overlap or a morpheme having distinct meanings within the overlap.

Let us check the principle (2) to show how it might function. In terms of property (2a1), it seems that there is a greater overlap of morpheme members between the V1 and V0 constituent types than that of the V2 and V0. If it is true, the class of first-position verbs would be more alike with the class of solo verbs, whereas the class of second-position verbs may show more divergence from the class of solo verbs. Furthermore, regarding to the overlapping portions of morpheme memberships, the members that can function both as V1 and V0 seem to have basically the same connotations across both usage, while certain of the morphemes that can function both as V2 and V0 have divergent meanings across the two usages. For instance, when guò "pass" appears as the V0 in the sentence Tā zóu-guò jiēdào "He walks through the street.", as Tã guò le malù "He crossed the street.", the morphemes do not have the same semantic content across the two usages, which shows semantic divergence. In Talmy's later publications (Talmy, 2000), a more generalized concept of path usually encompasses some other semantic categories, including aspect. Therefore, as to the property (2a3), the morphemes that denote aspect in V2 usage mainly express rather divergent meanings in V0 usage. Take hăo and wán for example: both of the two morphemes designate the aspectual concept "to completion" in their V2 usage, yet as V0, hăo means "be good"; and wán, to some extent, implies "be done for". Finally, in respect of (2b), according to Talmy, "a native speakers sense of the syntactic status of an individual V2 form seems directly affected by that form's V0 usage" (Talmy, cited in Ibarretxe-Antuñano, 2005). That is to say, if the form has almost the same meaning in both usages, one may think that V2 has a relatively prominent form; if the two usages are different, one regards the V2 as having a more subordinate role. The experiment he takes demonstrate that: in sentence Tā zǒu-jìn le jiàoshì "He walked into the classroom.", subjects cannot tell which one - V1 (zǒu) or V2 (jìn) functions as a main verb; but when V2 form is occupied by guò, their feeling is that the V1, zóu is undoubtedly the main verb, whereas the V2 guò is subordinate.

Therefore, Talmy (ibid.) lands on the conclusion: the situation in Chinese seems to be that, “...in a serial verb construction representing motion or one of its semantic extensions, the V1 constituent type clearly has main verb status, while the V2 constituent type is in the process of diverging toward a subordinate status as a satellite to the main verb". As we mentioned before, typically in Chinese, V1 represents the manner or cause, and V2 indicates the component of path, thus, according to Talmy, Chinese belongs to satellite-framed language in that it encodes the core information of path of movement in the subordinate satellite element associated with a verb.

In addition, Shen (2003, p. 22), who conducts a study on "typology of verb-complement structure in modern Chinese", considers Chinese as satellite-framed language but not a typical one.

\section{B. Chinese as a Verb-framed Language}

Talmy's claim that Chinese is a satellite-framed language has been challenged by Tai (2003). Tai argues that Chinese is primarily a verb-framed language, on the basis of the evidence that the path verb rather than the manner verb is the main verb. From the perspective of resultative construction in Chinese, he proposes that the resultative complement V2 appears to express foreground information, and the action verb V1 seems to designate background information. This can be best illustrated by following examples from Tai (2003):

(8) *I killed John, but he didn't die.

(9) 我杀了约翰两次, 他都没有死。

Wǒ shā le yuēhàn liăng cì, tā dōu méiyǒu sǐ.

I kill LE John twice CL he all not have die

"I performed the action of attempting to kill John twice, but he didn't die."

The verb shā in Chinese is assumed most equivalent to kill in English in English-Chinese and Chinese-English dictionaries. The verb kill necessarily implies the death of the recipient of the action; nevertheless, the verb shā, as shown in (9), doesn't necessarily imply the death of the recipient of the action. To guarantee the death of the recipient of the action, the verb compound $s h \bar{a}$ sǐ has to be used. The ungrammaticality of (10) demonstrates that sha sì does has just about the same meaning of kill.

(10) * 我杀死了约翰两次, 他都没有死。

Wǒ shā si le yuēhàn liăng cì, tā dōu méiyǒu š̌.

I kill dead LE John twice CL he all not have die

“*I killed John twice, but he didn't die."

Besides, many of the verbs in English are expressed by action-result verb compounds in Chinese: see is kàn-dào "look-reach", hear is tīng-dào "listen-reach", find is zhăo-dào "seek-reach", and receive is shōu-dào "collect-reach". 
These resultative verb compounds behave semantically and syntactically no different from those equivalents to verbs in English that mentioned above.

Therefore, it is inevitable to identify the "main verb" or "head" in these action-result verb compounds in Chinese. The dominant view holds that the first component of the compounds which represent action is "main verb" or "head" (Chao, 1968; Li \& Thompson, 1989; Huang, 1988; Chang, 2001). A different view has been proposed by Tai (1973) and Hsueh (1989) which regards the second part, i.e., the so-called "complement", as the "head". According to Tai (2003), if “...we accept 'result' as a semantic prime underlying action-result verb compounds, it makes sense to take the second element as the center of predication, even though it cannot be analyzed as an independent transitive verb in

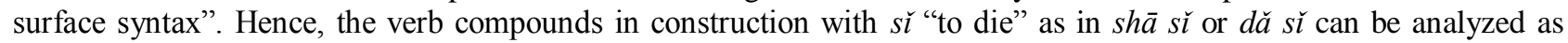
"cause to die", that is to say, as second element of the compound, it is really equivalent to kill in English and thus functions as the center of predication. The action verbs in these compounds, however, function like manner adverbs. In his opinion, in fact, the first element in verb compounds with š̌ doesn't have to be a verb by itself (Tai, 2003). For example, dú in (11) and qì in (13) cannot stand alone as a verb as illustrated in (12) and (14), respectively.

(11) 他们毒死了约翰。

Tāmen dú sǐ le yuēhàn.

they poison dead LE John

"They killed John with poison."

(12) *他们毒了约翰。

Tāmen dú le yuēhàn.

they poison LE John

"They poisoned John."

(13) 这件事气死了约翰。

Zhè jiàn shì qì sǐ le yuēhàn.

this CL case infuriate dead LE John

"This case infuriated John to death."

(14) *这件事气了约翰。

Zhè jiàn shì qì le yuehàn.

this CL case infuriate LE John

"This matter infuriated John."

Talmy (2002) treats the resultative complement as the satellite rather than verb root in Chinese, which in accordance with his support that the V1 is the main verb. While Tai (2003) suggests that in Chinese action-result verb compounds (V1-V2), V1 expresses the cause, yet presents the subordinate event; while V2 expresses the result, but presents the main event. Therefore, V2 can be considered as the main verb. If so, then Chinese is no longer a satellite-framed language as Talmy claims. Rather, it makes more sense to treat Chinese as primarily a verb-framed language and only secondarily a satellite-framed language.

\section{Chinese as an Equipollently-framed Language}

Slobin (2004) revises Talmy's binary typology by adding a third type. According to him, in addition to the original types of verb-framed and satellite-framed languages, there are other languages (e.g., Chinese) that may be best characterized as equipollently-framed, for which the specifications of path and manner information are achieved by equivalent grammatical forms.

"Because the path verbs can occur alone, they cannot be regarded as satellites, which are verb particles and affixes that do not occur alone. ...It may be most appropriate to treat serial-verb languages as a third typological category with regard to motion events. ... [I] propose ... a third type be added, equipollently-framed languages, to include serial-verb languages and other types of languages in which both manner and path are expressed by 'equipollent' elements, - that is, elements that are equal in formal linguistic terms..." (Slobin, 2004, p. 228)

Following Slobin's work, Chen (2005) examines the habitual patterns of motion event descriptions in spoken narratives elicited from Chinese speakers using the wordless picture storybook Frog, where are you? (Mayer, 1969); also, he investigates the development of motion event descriptions by Chinese children through an examination of the spoken narratives produced by children from different age groups in comparison with adult narratives. These studies, on the whole, suggest that Equipollently-framed structural patterns of motion event descriptions are found in Chinese. Chen and Guo (2009) examine the use of motion events in nine Chinese novels. The results of both studies demonstrated that the structural and discourse characteristics of Chinese did not completely pattern with those of either S-languages or V-languages, yet instead showed hybrid patterns that are characteristic of both types. Therefore, Chen and Guo advocate that Chinese should be categorized as an E-language, as is suggested by Slobin. This proposal for a third type reveals the difficulty in classifying serial-verb languages like Chinese into a strict binary typology.

In addition, Wen and Shan (to appear) examines the ways in which Mandarin speakers conceptualize motion events by using the famous cartoon volume in China Winter of Three Hairs (Volume I) (Zhang, 1982). According to them, there are three subtypes of the "manner + verb serial constructions" in Mandarin; while the first two belong to the "verb + verb construction", the last subtype is the "verb + satellite construction". Furthermore, the results are in turn applied 
to a set of properties proposed by Talmy $(2005,2016)$ as identifying main verb status in a construction, exploring that Equipollent framing holds a dominant position in Mandarin.

\section{CONCLUSION}

The present paper has provided an overview of research on motion event from a typological perspective. The pioneer researches of Talmy's linguistic typology of motion events and Slobin's "Thinking for Speaking” hypothesis are introduced, and discussions of the place of Chinese in motion event typology are presented. However, as we have mentioned, translational motion, i.e., motion with a change of location, is the major concern in these literature. We hope that other motion expressions - metaphorical motion expressions such as Christmas is drawing near and subjective motion expressions such as The road goes along with the railway track - which shares properties with literal motion as well, would be studied within the framework of typology in the future and the results would provide new insights to some controversial issues.

\section{ACKNOWLEDGEMENTS}

This study is supported by "the Fundamental Research Funds for the Central Universities" (Project No.: SWU1609301).

\section{REFERENCES}

[1] Ameka, F. K. \& J. Essegbey. (2006). Elements of the grammar of space in Ewe. In S. C. Levinson \& D. Wilkins (Eds.), Grammars of Space. Cambridge: Cambridge University Press, 359-398.

[2] Berman, R. A. \& D. I. Slobin. (1994). Relating events in narrative: A crosslinguistic, developmental study. Hillsdale, NJ: Lawrence Erlbaum Associates.

[3] Bohnemeyer, J. et al. (2007). Principles of event segmentation in language: The case of motion events. Language, 83, 1-38.

[4] Chang, Jung-hsing. (2001). The Syntax of Event Structure in Chinese. Ph.D. dissertation, University of Hawaii at Honolulu.

[5] Chao, Y. (1968). A grammar of spoken Chinese. Berkeley: University of California Press.

[6] Chen, L. (2005). The acquisition and use of motion event expressions in Chinese. Ph.D. dissertation, University of Louisiana at Lafayette.

[7] Chen, L., \& J. Guo. (2009). Motion events in Chinese novels: Evidence for an equivalently-framed language. Journal of Pragmatics, 41, 1749-1766.

[8] Croft, W., J. Barðdal, W. Hollman, V. Sotirova. \& C. Taoka. (2002). Revising Talmy's typological classification of complex events. In H. C. Boas (Ed.), Contrastive Construction Grammar. Amsterdam: John Benjamins, 201-236.

[9] Gennari, S., S. Sloman, B. Malt. \& W. Fitch. (2002). Motion events in language and cognition. Cognition, 83, 49-79.

[10] Goldberg, A. (1998). Patterns of experience in patterns of language. In M. Tomasello (Ed.), The new psychology of language: Cognitive and functional approaches to language structure, 203-219.

[11] Huang, J. C.-T. (1988). Wo pao de kuai and Chinese phrase structure. Language, 64, 274-311.

[12] Hsueh, F. (1989). The structure meaning of Ba and Bei constructions in Mandarin Chinese. In J. Tai \& F. Hsueh (Eds.), Functionalism and Chinese grammar. South Orange, NJ: Chinese Language Teachers Association, 95-125.

[13] Ibarretxe-Antuñano, I. (2004). Linguistic typologies in our language use: The case of Basque motion events in adult oral narratives. Cognitive linguistics, 15 (3), 317-49.

[14] Ibarretxe-Antuñano, I. (2005). Leonard Talmy. A windowing to conceptual structure and language. Part 1: Lexicalisation and typology. Annual review of cognitive linguistics, 3, 325-347.

[15] Li, C. \& S. Thompson. (1989). Mandarin Chinese: A functional reference grammar. Berkeley: University of California Press.

[16] Mayer, M. (1969). Frog, Where Are You? New York: Dial Press.

[17] Papafragou, A., C. Massey. \& L. Gleitman. (2006). When English proposes what Greek presupposes: The cross-linguistic encoding of motion events. Cognition, 98, B75-B87.

[18] Shen, J. X. (2003). The resultative construction in Chinese: a typological perspective. Chinese Teaching in the World, 3, 17-23.

[19] Slobin, D. I. (1991). Learning to think for speaking: Native language, cognition, and rhetorical style. Pragmatics, 1, 7-26.

[20] Slobin, D. I. (1996a). From "thought and language" to "thinking for speaking". In J. J. Gumperz \& S. C. Levinson (Eds.), Rethinking linguistic relativity. Cambridge: Cambridge University Press, 70-96.

[21] Slobin, D. I. (1996b). Two ways to travel: Verbs of motion in English and Spanish. In M. Shibatani \& S. A. Thompson (Eds.), Grammatical constructions: Their form and meaning. Oxford: Oxford University Press, 195-217.

[22] Slobin, D. I. (1997a). The Crosslinguistic Study of Language Acquisition. Mahwah, NJ: Lawrence Erlbaum Associates.

[23] Slobin, D I. (1997b). Mind, code, and text. In J. Bybee, J. Haiman \& S. A. Thompson (Eds.), Essays on language function and language type: Dedicated to T. Givón. Amsterdam/Phildaelphia: John Benjamins, 437-467.

[24] Slobin, D. I. (2000). Verbalized events: A dynamic approach to linguistic relativity and determinism. In S. Niemeier \& R. Dirven (Eds.), Evidence for Linguistic Relativity. Berlin: Mouton de Gruyter, 107-138.

[25] Slobin, D. I. (2003). Language and thought online: Cognitive consequences of linguistic relativity. In D. Gentner \& S. Goldin-Meadow (Eds.), Advances in the Investigation of Language and Thought. Cambridge, MA: MIT Press, 157-192.

[26] Slobin, D. I. (2004). The many ways to search for a frog: Linguistic typology and the expression of motion events. In S. Strömqvist \& L. Verhoeven (Eds.), Relating events in narrative: Typological and contextual perspectives. Mahwah, NJ: Lawrence Erlbaum Associates, 219-257.

[27] Slobin, D. I. \& N. Hoiting. (1994). Reference to movement in spoken and signed languages: Typological considerations. Proceedings of the Twentieth Annual Meeting of the Berkeley Linguistics Society, 487-505. 
[28] Tai, J. H-Y. (1973). A derivational constraint on adverbial placement in Mandarin Chinese. Journal of Chinese Linguistics, 1 , 397-413.

[29] Tai, J. H-Y. (2003). Cognitive relativism: Resultative construction in Chinese. Language and Linguistics, 4, 301-316.

[30] Talmy, L. (1972). Semantic structures in English and Atsugewi. Ph.D. dissertation, University of California at Berkeley.

[31] Talmy, L. (1985). Lexicalization patterns: Semantic structure in lexical forms. In T. Shopen (Ed.), Language typology and semantic description: Vol. 3: Grammatical categories and the lexicon. Cambridge: Cambridge University Press, 36-149.

[32] Talmy, L. (1991). Path to realization: A typology of event conflation. Proceedings of the Seventeenth Annual Meeting of the Berkeley Linguistics Society, 480-519.

[33] Talmy, L. (2000). Toward a Cognitive Semantics: Vol. II: Typology and Process in Concept Structuring. Cambridge, MA: MIT Press.

[34] Talmy, L. (2005). The fundamental system of spatial schemas in language. In B. Hampe (Ed.), From perception to meaning: Image schemas in cognitive linguistics. Berlin: Mouton de Gruyter, 199-234.

[35] Talmy, L. (2016). Properties of main verbs. Cognitive Semantics, 2, 133-163.

[36] Wen, X. \& Shan, X. X. The adventure of a third way: Motion events in Mandarin. Language Sciences, to appear.

[37] Zlatev, J. \& P. Yangklang. (2002). A third way to travel: The place of Thai and serial verb languages in motion event typology. In S. Strömqvist \& L. Verhoeven (Eds.), Relating events in narrative: Typological and contextual perspectives. Mahwah, NJ: Lawrence Erlbaum Associates, 219-257.

Xinxin Shan was born in Hunan Province, China. She received her MA degree in linguistics from Southwest University, China in 2012. She is currently a Ph.D. candidate in the College of International Studies, Southwest University, Chongqing, China. Her research interests include cognitive linguistics and psycholinguistics. 